\title{
A Comprehensive Study of the Reasons for Underpriced IPOs
}

\author{
Kelai Wang ${ }^{1, *}$ \\ ${ }^{1}$ SSEES Department, University College London, London, UK \\ *Corresponding author. Email: wangkelai2000@126.com
}

\begin{abstract}
The paper reviews mainstream explanations of the underpricing of IPOs and aims to locate the most logical explanation among both existing literature and hypotheses to be corroborated. The author divides current literature into two groups, informational explanations and non-informational explanations. Informational explanations are further differentiated into three types; by characters of both parties in an asymmetric information situation, issuers vs. investors, underwriters vs. investors and investors vs. investors. For non-informational explanations, there is Legal Cost by Ibbotson and Takeover Defence by Booth and Chua. Among mentioned literature, the author identified strong evidence for the Winners Curse Model via the corroboration of a recent paper published in 2018, as well as the Bookbuilding Theory. Furthermore, the author concluded that there are scopes for future research in machine learning. It can be further studied that which features determine the quality of a firm and which model or what combinations of models can well explain the mispricing. Finally, the author hypothesized that overprinting of U.S. dollars can increase informed investments. According to the Winners Curse Model, IPOs have to be more underpriced to keep the uninformed investors stay.
\end{abstract}

Keywords: Initial Public Offerings, Underpricing, Information Asymmetry, Machine Learning, Interest Rate

\section{INTRODUCTION}

Theories of underperformance of IPO are acknowledged to be a well-researched area. Nonetheless, it remains one of the fascinating puzzles in finance. Over the past decades, there has been significant evidence that shows positive initial market performance. Since the results show few departures from the aftermarket efficiency, positive initial market performance can only be attributed to the overall underpricing of IPOs' offerings [1]. Smith (1986) concludes that, on average, underpricing exceeds $15 \%$ [2]. However, the extent of underpricing varies across periods, industries and types of IPO [1].

Moreover, apart from the relatively low IPO price, there has also been a long-term underperformance of IPO shares than peer companies. Loughran and Ritter (1991); Portfolio underperforms "similar" companies by $30 \%$. This underperformance issue is severe, especially for smaller firms [3]. One possible explanation could be that it is the overvalued firms that tend to undertake
IPOs. Therefore, over time their performance is less good.

This paper reviews the development of underpricing theories, and their pros and cons are discussed. The author gives the opinion of the existing literature that she thinks best fits. Furthermore, the discussion and conclusion section also refer to some alternative explanations according to the global environment and future research scopes.

\section{ANALYSIS}

\subsection{Noninformational Theories of Underpricing}

Main theories can be divided into five subgroups: 3 theories based on informational asymmetry and two other theories. First, the non-informational theories of underpricing have a potential one-sided risk due to fixed price constraints. Since the price set cannot always be precisely what the firm is valued, share prices are likely undervalued. Ibbotson in 1975 attempted to explain 
from the view of Legal Costs; going public involves making many 'self-revelatory' statements. According to prospect theory, people strongly prefer avoiding losses than they do acquire gains. Thus people are unhappy if the price falls. Assuming that happier investors are less likely to sue, the firm may incur a less legal cost. However, there is little evidence in support of this argument. Drake and Vetsuypens, in 1993, have found that highly underpriced IPOs are sued more often [4]. Ibbotson has also listed a few possible reasons, including irrational behaviour, legal constraints and side payments from underwriters to issuers to compensate their loss in underpriced offerings. Nonetheless, the valid reason for this underpriced puzzle remains unsolved.

Booth and Chua founded the other non-informational theory in 1996. They interpreted the low offering price as a way for the current management to defend the takeover by some cantankerous shareholders willing to control the firm via holding a mass of shares. Underpricing can generate excessive demand so that managers may be able to disperse the ownership. Information costs are essential in underpricing. Since underwriter reputation plays a more significant role in firm-commitment IPOs than in best-efforts IPOs, bestefforts are generally more underpriced than a firmcommitment type of IPOs [5]. So their results suggest a positive correlation between underpricing and ownership dispersion due to information cost. However, similarly, the evidence for this theory is weak.

\subsection{Informational Theories of Underpricing}

For informational theories of underpricing, theories can be divided into three parts, all caused by asymmetric information. The first one is between issuers and investors (e.g., Allen and Faulhaber, 1989; Chemmanur, 1993). The second one is between underwriters and investors (Benveniste and Spindt, 1989) and the last one is between informed investors non informed investors (Rock 1982, 1986, Beatty and Ritter 1986).

For asymmetric information between issuers and investors, according to Ibbotson, high-value firms tend to signal investors by accepting low IPO prices to 'leave a good taste in investors' mouths' in new issues [6]. Hence, future underwritings by the same issuer can underwrite more satisfying prices. As only good firms can recoup their loss from underpriced initial IPOs by showing their better performance, later on, they can afford the signaling costs, vice versa. Therefore, the model provides explanations of why underpricing exists as a way for an excellent firm to differentiate its quality from the bad. Besides, firms go public in the hope of gaining publicity and underpricing can help firms with that. Since information asymmetry can be costly to reduce, only a lower IPO share price will induce more outsiders to produce information [7]. However, the evidence for this explanation is mixed. Keloharju in 1993 had proved the core idea of Ibbotson where underpricing is a way to "leave a good taste in the mouths of investors" in Finland [8]. However, the result is a no in the U.S. by Michaely and Shaw 1994. They do not find empirical support for the dividend signaling models explaining why firms are underpriced [9].

With investors knowing more than underwriters, Benveniste and Spindt in 1989 took an auction-design approach to model the pricing of IPOs. It is argued that the underprice is caused by the underwriters' intention to extract from "regular IPO investors" information that is useful in setting the IPO offer price [7]. However, investors have no incentive to present their interest in the roadshow for their own well-being. So IPO offer prices should be set low to provide profit to compensate investors for revealing positive information. It is called the Bookbuilding theory [10]. Hanley in 1993 proved precisely this; the IPOs in which price is above the initial range should be most underpriced. However, long-term performance is unrelated to revisions in offer prices [11].

Finally, and this is a well-studied topic, asymmetric information among investors. Some investors are more informed than others. In other words, they have better knowledge of the quality of firms, which firms are underpriced or overpriced. Winners Curse Model was developed by papers of Rock in 1986, also in the paper written by Beatty and Ritter in the same year. Rock argues that underpriced IPOs should compensate the informed investors for the cost of gaining extra information [12]. Beatty and Ritter provided empirical evidence in support of a positive relationship between the ex-ante uncertainty about an initial public offering's value and its expected initial return.

Moreover, underpricing equilibrium is enforced via the investment banking industry [13]. Due to capital constraints, it is assumed that the stock market is not filled entirely by informed investors. IPOs must be set underpriced to keep the less informed investors within the market. Koh and Walter have proved valid for Singapore and Levis for the UK that there is enough evidence to show that Underpricing is just sufficient to produce zero returns for uninformed investors [14][15].

\subsection{Machine Learning Applications in IPOs}

Machine learning algorithms have made trading faster and easier by identifying the patterns in the market, assessing the investment risks, and analyzing the sentiments of the people [18]. Machine learning has been vastly applied in the finance sector, aiming for stock price prediction since 2015. There have been increasing numbers of papers in IPOs' underpricing area in recent years [19]. Despite possible informational asymmetry, it is assumed that the market works 
perfectly efficiently most of the time. Therefore, it may be difficult for investors to arbitrage in underpriced IPOs via machine learning since all other investment institutions apply the same machine learning techniques. Moreover, price predictions can be intricate as all factors need to be considered: government intervention, subsidies in specific industries like environmental protection, international relations, or variations in human expectations and purchasing flavour.

However, machine learning has great potential for IPOs ' price prediction, not altering people' s behaviour but by evolving themselves through algorithms and unsupervised learning. Big data provides supports for that.

\section{DISCUSSION}

Among the works of literature mentioned above, the evidence for the Winners Curse Model is strong. Underpricing is likely to be just sufficient in providing zero returns for uninformed investors. Therefore, the underpricing problem might be deduced to be more severe for markets with more retail investors like China. Paper by Alcino Azevedo, Yilmaz Guneyb, Jingsi Leng in 2018 has proved it; noticeably, the average IPO underpricing in China between 1990 and 2000 is $256.9 \%$, which is vast compared to the U.S's $18.4 \%$ between 1980 and 2001, illustrated in Figure 1 [16][17].

\begin{tabular}{|c|c|c|c|c|}
\hline Country & Source & $\begin{array}{l}\text { Sample } \\
\text { size }\end{array}$ & $\begin{array}{l}\text { Time } \\
\text { period }\end{array}$ & $\begin{array}{l}\text { Avg. initial } \\
\text { return }(\%)\end{array}$ \\
\hline Australia & Lee, Taylor \& Walter; Woo & 381 & $1976-1995$ & 12.1 \\
\hline Austria & Aussenegg & 83 & 1984-2002 & 6.3 \\
\hline Belgium & Rogiers, Manigart \& Ooghe; Manigart & 86 & 1984-1999 & 14.6 \\
\hline Brazil & Aggarwal, Leal \& Hernandez & 62 & $1979-1990$ & 78.5 \\
\hline Canada & Jog \& Riding; Jog \& Srivastava; Kryzanowski \& Rakita & 500 & 1971-1999 & 6.3 \\
\hline Chile & Aggarwal, Leal \& Hernandez; Celis \& Maturana & 55 & $1982-1997$ & 8.8 \\
\hline China & Datar \& Mao; Gu and Qin (A shares) & 432 & 1990-2000 & 256.9 \\
\hline Denmark & Jakobsen \& Sorensen & 117 & 1984-1998 & 5.4 \\
\hline Finland & Keloharju; Westerholm & 99 & 1984-1997 & 10.1 \\
\hline France & $\begin{array}{l}\text { Husson \& Jacquillat; Leleux \& Muzyka; Paliard \& Belletante; Derrien \& } \\
\text { Womack; Chahine }\end{array}$ & 571 & $1983-2000$ & 11.6 \\
\hline Germany & Ljungqvist & 407 & $1978-1999$ & 27.7 \\
\hline Greece & Kazantzis \& Thomas; Nounis & 338 & 1987-2002 & 49.0 \\
\hline Hong Kong & McGuinness; Zhao \& Wu; Ljungqvist and Yu & 857 & $1980-2001$ & 17.3 \\
\hline India & Krishnamurti \& Kumar & 98 & $1992-1993$ & 35.3 \\
\hline Indonesia & Hanafi; Ljungqvist \& Yu & 237 & 1989-2001 & 19.7 \\
\hline Israel & Kandel, Sarig \& Wohl; Amihud, Hauser \& Kirsh & 285 & 1990-1994 & 12.1 \\
\hline Italy & Arosio, Giudici \& Paleari; Cassia, Paleari \& Redondi & 181 & $1985-2001$ & 21.7 \\
\hline Japan & $\begin{array}{l}\text { Fukuda; Dawson \& Hiraki; Hebner \& Hiraki; Hamao, Packer, \&Ritter; } \\
\text { Kaneko \& Pettway }\end{array}$ & 1,689 & $1970-2001$ & 28.4 \\
\hline Korea & Dhatt, Kim \& Lim; Ihm; Choi \& Heo & 477 & $1980-1996$ & 74.3 \\
\hline Malaysia & Isa; Isa \& Yong & 401 & $1980-1998$ & 104.1 \\
\hline Mexico & Aggarwal, Leal \& Hernandez & 37 & $1987-1990$ & 33.0 \\
\hline Netherlands & Wessels; Eijgenhuijsen \& Buijs; Ljungqvist, Jenkinson \& Wilhelm & 143 & $1982-1999$ & 10.2 \\
\hline New Zealand & Vos \& Cheung; Camp \& Munro & 201 & $1979-1999$ & 23.0 \\
\hline Nigeria & Ikoku & 63 & $1989-1993$ & 19.1 \\
\hline Country & Source & $\begin{array}{l}\text { Sample } \\
\text { size }\end{array}$ & $\begin{array}{l}\text { Time } \\
\text { period }\end{array}$ & $\begin{array}{l}\text { Avg. initial } \\
\text { return }(\%)\end{array}$ \\
\hline Norway & Emilsen, Pedersen \& Saettern & 68 & 1984-1996 & 12.5 \\
\hline Philippines & Sullivan \& Unite & 104 & $1987-1997$ & 22.7 \\
\hline Poland & Jelic \& Briston & 140 & 1991-1998 & 27.4 \\
\hline Portugal & Almeida \& Duque & 21 & $1992-1998$ & 10.6 \\
\hline Singapore & Lee, Taylor \& Walter; Dawson & 441 & 1973-2001 & 29.5 \\
\hline South Africa & Page \& Reyneke & 118 & $1980-1991$ & 32.7 \\
\hline Spain & Ansotegui \& Fabregat; Otero & 99 & 1986-1998 & 10.7 \\
\hline Sweden & Rydqvist; Schuster & 332 & 1980-1998 & 30.5 \\
\hline Switzerland & Drobetz, Kammermann \& Walchli & 120 & $1983-2000$ & 34.9 \\
\hline Taiwan & Lin \& Sheu; Liaw, Liu \& Wei & 293 & 1986-1998 & 31.1 \\
\hline Thailand & Wethyavivorn \& Koo-smith; Lonkani \& Tirapat & 292 & $1987-1997$ & 46.7 \\
\hline Turkey & Kiymaz; Durukan & 163 & 1990-1996 & 13.1 \\
\hline UK & Dimson; Levis; Ljungqvist & 3,122 & $1959-2001$ & 17.4 \\
\hline USA & Ibbotson, Sindelar \& Ritter & 14,840 & $1960-2001$ & 18.4 \\
\hline
\end{tabular}

Figure 1 Average initial returns for countries

Another explanation that seems more credible with evidence is the Bookbuilding Theory, which is also within the informational asymmetry division of this paper. If underpricing rewards investors for information, they should be rewarded precisely when they provide information [10]. There is a behavioural issue that investors tend not to show their interests in the roadshow; if they do, the price of issuing will reflect the exact amount of demand from investors. Investors would fail to take advantage of underwriters via asymmetric information. Therefore, the author strongly agrees that underpricing is primarily caused by information asymmetry. However, the author has come up with a couple of hypotheses of underpricing, taking 
the global economic environment and politics into account.

In addition, an alternative hypothesis could be that the overprinting of U.S. dollars causes IPOs underpricing; assume there is a higher percentage among the high income group to have better knowledge in primary market, and these informed investors are more likely to invest their money in real estate and stock market. According to the Winners Curse Model, with more informed investors within the market, IPOs have to be more underpriced to keep the uninformed investors stay. Hence, IPOs underpricing could be because of the macro environment, the U.S. Fed's excess money supply. Furthermore, with the U.S. dollars flooding into other countries which also use dollars, it would cause inflation countrywide. Then with the U.S. adjusting its Central Bank's interest rate, hot money inflows back to the U.S., leading to a slump in other countries' stock prices generally. Hence, the underpricing of their IPOs. What is more, for countries with a higher percentage of state controls, regulations may have a more significant impact on the prices of IPOs, instead of by information asymmetry.

\section{CONCLUSION}

This paper concludes five mainstream opinions of possible causes why IPOs are mostly underpriced. Among them, three are based on informational asymmetry. The results turn out that the evidence for Bookbuilding Theory and Winners Curse Model is strong, of which both belong to the informational asymmetry division of this paper. Therefore, the author concludes that underpricing is primarily caused by information asymmetry. Moreover, the author has provided another possible (non) informational explanations for addressing the cause of underpricing based on global environments, floods of U.S. dollars, and the level of state controls and regulations.

For further studies, machine learning has become an increasingly popular technique to measure the quality of a firm. Will it be underpriced or overpriced in the IPO?

The author suggests that future research could focus on finding out the specific features of firms that lead to more precise firms' valuations. Many non-economic features can actually be more critical than economic features, such as the environment in which the company is listing; whether it is capital friendly and whether it is listed in the appropriate timing when the dollar flows back to the United States through monetary policy. Furthermore, the enterprise must generate societal benefit, and the use of massive bank leverage creates risks, as well as the possibility of international political security risks. Similar factors are not considered in the traditional banking model. In addition, in countries with non-bipartisan systems, whether long-term national economic and development plans can empower this enterprise, such as the so-called five-year plan and carbon-neutral plan, will definitely underestimate the stock price in the short term. However, it is hard to say in the long term. In bipartisan countries, more political support and political contributions will be involved in stocks. In addition, speculators will be predominantly (short-term investors), and personal social influence abuse (Musk) will also amplify uncertainty. The above features can only be added artificially into models because it requires an understanding of various economic and political forecasts and news. Apart from feature-based predictions, the model or combinations of models in making predictions also need more in-depth investigation. That would help to explore the explanations of IPO mispricing.

The literature reviewed in this paper is classic and mainstreamed. However, it is mostly old. Since there are over 25,000 papers in relative fields, only the most representative papers are selected based on the author's judgment. This paper does not consider regional divisions nor branch theories. Hence, this paper is designed mainly for people who have little prior knowledge and would like to gain an insight into the existing examinations of why IPOs are underpriced. Also, this review paper is based on the author's own analysis and summary of the literature; although it tries to remain objective in the analysis process based on second-hand data, it may sill be highly subjective, since findings are based on personal opinions.

\section{ACKNOWLEDGMENT}

First of all, I would like to thank my mother, Jimin Chen, for providing me all the financial support needed in academic studying and researching. Also, thank you, professor Colleen Honigsberg, with whom I have spent six weeks together and replenished me with relevant finance and accounting knowledge. Finally, LSE summer school has greatly inspired me with the topic of IPO. I have found the course material very valuable for finance studying.

\section{REFERENCES}

[1] Ibboton, Roger G., 1975, Price performance of common stock new issues. Journal of Financial Economics 2, 235-272.

[2] Smith, Clifford W., 1986, Investment banking and the capital acquisition process, Journal of Financial Economics 15, 3-29.

[3] Ritter, Jay R., 1991, The long-run performance of initial public offerings, Journal of Finance 46, 3-27.

[4] Drake, Philip D., and Michael R. Vetsuypens, 1993, IPO underpricing and insurance against legal liability, Financial Management 22, 64- 73. 
[5] Booth, James R., and Lena Chua, 1996, Ownership dispersion, costly information, and IPO underpricing, Journal of Financial Economics 41, $291-310$.

[6] Allen, Franklin and Gerald R. Faulhaber, 1989, Signaling by underpricing in the IPO market, Journal of Financial Economics 23, 303-323.

[7] Chemmanur, Thomas J., 1993, The pricing of initial public offers: A dynamic model with information production, Journal of Finance 48, 2855304.

[8] Keloharju, Matti, 1993, The winner's curse, legal liability, and the long-run price performance of initial public offerings in Finland, Journal of Financial Economics 34, 251-277.

[9] Michaely, Roni, and Wayne H. Shaw, 1994, The pricing of initial public offerings: Tests of adverseselection and signaling theories, Review of Financial Studies 7, 279-319.

[10] Benveniste, L.M., Spindt, P.A., 1989, How investment bankers determine the overprice and allocation of new issues. Journal of Financial Economics 24,343-362.

[11] Hanley, Kathleen Weiss, 1993, The underpricing of initial public offerings and the partial adjustment phenomena, Journal of Financial Economics 34, 177-197.

[12] Rock, K., 1986. Why new issues are underpriced. Journal of Financial Economics 15,187-212.

[13] Beatty, Randolph P., and Ritter, Jay R. (1986), "Investment Banking, Reputation, and the Underpricing of Initial Public Offerings," Journal of Financial Economics, 15 (January/February), 213-32.

[14] Koh,F. and T. Walter, 1989, A direct test of Rock's model of the pricing of the unseasoned issues, Journal of Financial Economics 23, 251-272

[15] Levis, M., 1990, The winner's curse problem, interest costs, and the underpricing of initial public offerings, Economic Journal, 76-89.

[16] Azevedo, A., Guney, Y., Leng, J., 2018, 'Initial public offerings in China: underpricing, statistics and developing literature'. Res. Int. Bus. Financ. 46, 387-398.

[17] Ritter, J., 2003, Difference between European and American IPO markets. European Financial Management 9, 421-434.

[18] Rafia, 2020, Applications of Machine Learning Algorithms for https://logicai.io/blog/applications-machinelearning-trading/

[19] Robert Hillman, 2015, Machine Learning in Finance - 25 Years On, https://www.linkedin.com/pulse/machine-learningfinance-25-years-robert-hillman 